\title{
Margaret McCartney: The prurient interest in Trump and Clinton's health
}

\author{
Margaret McCartney general practitioner
}

Glasgow

\begin{abstract}
Mere weeks before the US presidential election a petition, \#DiagnoseTrump, is calling for more information about the Republican candidate's health because he "appears to exhibit all the symptoms of the mental disorder narcissistic personality disorder." 1
\end{abstract}

It goes on, "Mental health professionals need to come forward and urge the Republican Party to insist that their nominee has an evaluation to determine his mental fitness for the job." People are asked to sign if they think that Donald Trump exhibits the criteria necessary to fulfil the diagnosis listed in the Diagnostic and Statistical Manual of Mental Disorders.

The Atlantic, a US magazine, published an evaluation of Trump, written by a psychology professor who drew firm conclusions despite Trump having "declined to be interviewed." Is this OK? Of course not, and the American Psychiatric Association's

"Goldwater rule" makes clear that professionals should not offer public opinions on people they have not personally examined. ${ }^{3}$ US presidential elections are extraordinary affairs, particularly where medicine and politics intersect. Both would-be presidents have published letters from their doctors stating that they are fit for office. Hillary Clinton's says that she is in "excellent health" and has had several tests, including non-evidenced screening such as breast ultrasound and "gynaecologic exam." It details her medical and family history in a way that I find gruesomely intrusive. ${ }^{4}$

Trump, meanwhile, has released a medical report claiming that his test results are "astonishingly excellent," that he has "extraordinary" physical strength and stamina, and that his doctor "can state, unequivocally" that, if elected president, "he will be the healthiest individual ever elected to the presidency." It's hilarious - but it's also bizarre. Has Dr Bornstein, the author of Trump's missive, really compared the medical notes and muscular biceps of all US presidents ever?

Despite this, it's not right that thousands of members of the public, and several mental health professionals who have never seen him, are suggesting that Trump has a clinical diagnosis in need of documenting. ${ }^{6}$ Will people then vote on whether they think Trump psychiatrically fit? I suspect that most citizens lack evidence based information about what conditions lead to risk, and when. Stigma is alive and, sadly, well.

\section{It's not right that the public, and mental health professionals who have never seen him, are suggesting that Trump has a clinical diagnosis in need of documenting}

Last weekend Clinton may have fainted at a ceremony to commemorate the $9 / 11$ attacks. The press greeted this with hysteria laced with conspiracy theory, claiming that this, in addition to a coughing fit a few days before, indicate that something serious or secret is going on. This, they say, demands publication of a "fuller record" of her medical history. ${ }^{\text {? }}$

This is simply incredible: there is no need for potential presidents to publish their medical records. All that is needed is a private occupational assessment of candidates and a public conclusion of yes, no, or suitable for employment, with conditions attached.

It's obvious that Trump is sexist and racist. ${ }^{89} \mathrm{He}$ 's vile in his nastiness, undiplomatic, and offensive: a true dog's dinner of a presidential candidate, if you really hated your dog. But none of this means that he has a psychiatric condition. It just means that he's a horrible man.

\section{Competing interests: See www.bmj.com/about-bmj/freelance- contributors/margaret-mccartney.}

Provenance and peer review: Commissioned; not externally peer reviewed.

\footnotetext{
Change.org petition website. \#DiagnoseTrump. https://www.change.org/p/diagnosetrump. McAdams D. The mind of Donald Trump. Atlantic 2016 Jun. www.theatlantic.com/ magazine/archive/2016/06/the-mind-of-donald-trump/480771/.

3 American Psychiatric Association. The Goldwater rule: why breaking it is unethical and irresponsible. Aug 3 2016. https://www.psychiatry.org/news-room/apa-blogs/apa-blog/ 2016/08/the-goldwater-rule.

4 A letter from Hillary Clinton's doctor. New York Times 2016 Jul 28. www.nytimes.com/ interactive/2015/07/31/us/politics/hillary-clinton-doctor-letter.html.

5 Blake A. The strange tale of Donald Trump's doctor letter just got stranger. Washington Post 2016 Aug 27. https://www.washingtonpost.com/news/the-fix/wp/2016/08/27/the-
} strange-tale-of-donald-trumps-doctor-letter-just-got-stranger/. 
6 Alford H. Is Donald Trump actually a narcissist? Therapists weigh in! Vanity Fair 2015 Nov 11. www.vanityfair.com/news/2015/11/donald-trump-narcissism-therapists.

Cillizza C. Hillary Clinton's health just became a real issue in the presidential campaign. Washington Post 2016 Sep 11. https://www.washingtonpost.com/news/the-fix/wp/2016/ 09/11/hillary-clintons-health-just-became-a-real-issue-in-the-presidential-campaign/.

8 Cohen C. Donald Trump sexism tracker: every offensive comment in one place. Daily Telegraph 2016 Jun 4. www.telegraph.co.uk/women/politics/donald-trump-sexism-trackerevery-offensive-comment-in-one-place/.
9 Lopez G. Donald Trump's long history of racism, from the 1970s to 2016, explained. Vox 2016 Aug 26. www.vox.com/2016/7/25/12270880/donald-trump-racism-history.

Published by the BMJ Publishing Group Limited. For permission to use (where not already granted under a licence) please go to http://group.bmj.com/group/rights-licensing/ permissions 